\title{
CONTRIBUTIONS TO THE GENUS HETAERIA (ORCHIDACEAE: GOODYERINAE) IN VIETNAM
}

\author{
Jan Ponert ${ }^{1,2,5}$, T. B. VuOng ${ }^{3}$, N. Hanh ${ }^{4}$, T. T. Thanh ${ }^{4}$, N. T. Vy $y^{3}$, \\ R. RYBKOVÁ ${ }^{1} \&$ T. Q. TAM ${ }^{3}$ \\ ${ }^{1}$ Prague Botanical Garden, Nádvorní 134, CZ-171 00, Prague, Czech Republic \\ ${ }^{2}$ Department of Experimental Plant Biology, Faculty of Science, Charles University in Prague, \\ Viničná 5, CZ-128 44, Prague, Czech Republic \\ ${ }^{3}$ Institute of Tropical Biology, Viet Nam Academy of Science and Technology, 9/621 Hanoi highway, \\ Linh Trung Ward, Thu Duc District, Ho Chi Minh City, Vietnam \\ ${ }^{4}$ Hon Ba Nature Reserve, 28 Hung Vuong, TT Dien Khanh, Khanh Hoa province, Vietnam \\ ${ }^{5}$ Author for correspondence: ponert@natur.cuni.cz

\begin{abstract}
As a result of Hon Ba nature reserve survey, Hetaeria finlaysoniana, previously recorded from Thailand, Myanmar and southern China, is newly recorded from Vietnam. Description of studied plants is presented together with notes on ecology and photographic documentation. These plants were collected in southern Vietnam (Hon Ba Nature Reserve, Khanh Hoa), which is located quite far from other known localities and thus a larger distribution of this possibly overlooked species could be expected. Additionally, H. youngsayei is newly recorded from the same reserve, $540 \mathrm{~km}$ from the nearest previously known locality. Distribution of both species is discussed and an updated identification key for all Vietnamese members of the genus Hetaeria is presented.
\end{abstract}

KeY words: Hetaeria finlaysoniana, youngsayei, new record, distribution, Hon Ba, Khanh Hoa

Introduction. Hetaeria Blume is a genus of about 30 species (Pridgeon et al. 2003, Chen et al. 2012) belonging to the Goodyerinae subtribe of family Orchidaceae (subfamily Orchidoideae, tribe Cranichideae; Pridgeon et al. 2003). It is distributed from tropical Africa through tropical Asia to the Pacific islands (Pridgeon et al. 2003, Chen et al. 2012). There are 5 species reported to-date from Vietnam (Averyanov 2008); however, this number may not be final. Members of this genus are inconspicuous plants, often present in low densities of flowering individuals which can be easily overlooked by botanists. Moreover, the Vietnamese flora as whole with its very high diversity is still poorly explored (Averyanov et al. 2009).

Hetaeria finlaysoniana Seidenf. is a species similar to other taxa in which the labellum is narrowed toward the apex, often with a poorly differentiated epichile. It was first mentioned in 1832, in Wallich's catalogue as Etaeria elongata, but not validly described until 1840 when Lindely named it Goodyera elongata. Eventually Trimen made the combination Hetaeria elongata in 1885 but he overlooked the earlier use of the same epithet in 1859 by F.A.W. Miquel for a New Guinea species, now known as Vrydagzynea elongata Blume. Since Hetaeria elongata (Lindl.) Trimen is a homonym, and thus illegitimate, Seidenfaden proposed the new name $H$. finlaysoniana in 1997 . To date, this species has been recorded from Thailand, Myanmar (Ormerod \& Sathish Kumar 2003) and southern China (Guangxi, Hainan; Chen et al. 2012).

Material and methods. Plants were collected in the field and stored in plastic bag with a wet moss until planted in Prague Botanical Garden (CITES permission No: 12CZ022452). Plants were growing in a mix of Seramis, perlite, pumice and peat in a plastic pot and kept slightly shaded in a glasshouse with day / night temperature $(20-30) /(18-25)^{\circ} \mathrm{C}$. Pots were watered regularly to be still moist. When flowering in cultivation, photographs were taken using a digital camera with a macro lens (Canon EOS 60D with Canon Macro EF 100mm 1:2,8 L IS USM) or a digital camera mounted on a stereomicroscope (Canon EOS 60D on Olympus SZ X7). 


\section{Results and discussion}

Hetaeria finlaysoniana Seidenf., Contr. Orchid Fl. Thailand 13: 10. 1997 E Etaeria elongata Lindl., Wall. Cat. 1832, No. 7384, 18. nom. nud. $\equiv$ Goodyera elongata Lindl., Gen. Sp. Orchid. Pl. 494. $1840 \equiv$ Hetaeria elongata (Lindl.) Trimen, Syst. Cat. Fl. Pl. Ceylon: 10, 1885 [not (Blume) Miquel 1859]; Seidenf., Dansk Bot. Ark. 32(2): 99, fig. $61 \equiv$ Rhamphidia elongata (Lindl.) Lindl., J. Proc. Linn. Soc., Bot. 1: 181, 1857.

TYPE: Origin unknown, possibly Thailand, Surat Thani province (Seidenfaden 1997) (K 000873768 \& 000387653, Finlayson s.n. in Herb. Wallich 7384, Photo!). Fig. 1, 3.

Plants terrestrial, creeping, 40 to $50 \mathrm{~cm}$ tall. Rhizome elongate, creeping, glabrous. Stem erect, brown, 2.3-5.7 $\mathrm{mm}$ in diameter, bearing 4 to 5 leaves, scattered along stem while growing, clustered at stem apex when flowering, approximately $5-15 \mathrm{~cm}$ above the ground. Leaves oblong to elliptic, base obtuse, apex acute, blade $4.5-6.0 \times 2.5-3.0 \mathrm{~cm}$, glabrous, green with distinctly darker reticulate veins. Petiole-like base $1.5-2.0 \mathrm{~cm}$ long (including tubular sheath). Peduncle pubescent, pale green to brownish yellow, $20 \mathrm{~cm}$ long, $2 \mathrm{~mm}$ wide, with 3 sterile bracts $11-18 \mathrm{~mm}$ long. Rachis pubescent, about $15 \mathrm{~cm}$ long with subdensely arranged flowers. Floral bracts pubescent, pink, lanceolate, cymbiform, 5-8 $\mathrm{mm}$ long, shorter than ovary. Flowers not resupinate, half open, spaced on rachis into four sides, inflorescence slightly spirally twisted. Ovary pubescent, $8-12 \mathrm{~mm}$ long, $2 \mathrm{~mm}$ wide, placed nearly parallel to the longitudinal axis of the inflorescence. Sepals sparsely pubescent at outer side, oblong to ovate-oblong, 5-6 $\times$ 2.8-3.0 mm. Lateral sepals pink to reddish pink. Dorsal sepal pink to white. Lateral petals white, thin and translucent, rhombic-obovate, 5-6 × $3 \mathrm{~mm}$. Lip yellow, oblong-lanceolate, $4.5 \times 2.2 \mathrm{~mm}$, hypochile saccate, epichile attenuated into acuminate apex with involuted parts of margins. Column 2.0-2.5 mm long.

DistRIBUTION. So far, this species has been recorded from tropical evergreen forests in Chantaburi, Kanchanaburi and Surat Thani provinces in Thailand (Seidenfaden 1997, Pedersen 2011), Myanmar (Ormerod \& Sathish Kumar 2003) and provinces Guangxi and Hainan in southern China (Chen et al. 2012), nevertheless records from China require to be verified due to common confusion of taxa in this group (reviewer note). Material presented here was collected in Hon Ba reserve in Khanh Hoa province of southern Vietnam which is located relatively far from other collections and thus larger distribution could be proposed for this taxon, perhaps including also Cambodia.

Flowering TIME. Perhaps from January to the beginning of March in Hon Ba, February to April in Thailand (Pedersen 2011), March in Myanmar.

Pollination. We have not observed fruit production from any flower except those which were previously hand-pollinated. Based on this we propose that these plants are allogamous.

ECOLOGY. Plants were growing in leaf litter on a ground in evergreen tropical lowland primary forest with granite bedrock. The locality is in close proximity to the river, however prominently above the water level during periodical floods; the habitat is a rather dry slope in the broad-leaved forest. Other terrestrial orchids growing in the same place are Erythrorchis altissima (Blume) Blume and Zeuxine glandulosa King \& Pantl.. On more wet places along stream grows Neuwiedia zollingeri var. javanica (J.J.Sm.) de Vogel.

Specimens seen. Czech Republic, cultivated in Prague Botanical Garden, 13 March 2013 (originally collected in Vietnam, Khánh Hòa province, Cam Lâm District, Hòn Bà Nature Reserve, lowland evergreen forest near the Day river (Song Day), alt. 250 m, 4 March 2012), J. Ponert 523 (PRC!).

Hetaeria youngsayei Ormerod, Oasis Suppl. 3: 7, 2004 $\equiv$ Hetaeria shiuyingiana L.Li \& F.W.Xing, Novon 19: 187, 2009. Hetaeria nitida auct. non Ridl., J. Linn. Soc., Bot. 32: 404, 1896 - Fig. 2.

This species has been recorded from the province Ha Giang in northern Vietnam and province Quang Tri in central Vietnam under the name Hetaeria nitida Ridl. (Averyanov 2008) which was misapplied for this taxon many times (see Ormerod, 2004). Our collection was made in Khanh Hoa province, about $540 \mathrm{~km}$ as the crow flies far from the nearest locality in Quang Tri province, and it is the first record for southern part of Vietnam. Interestingly this species has been 

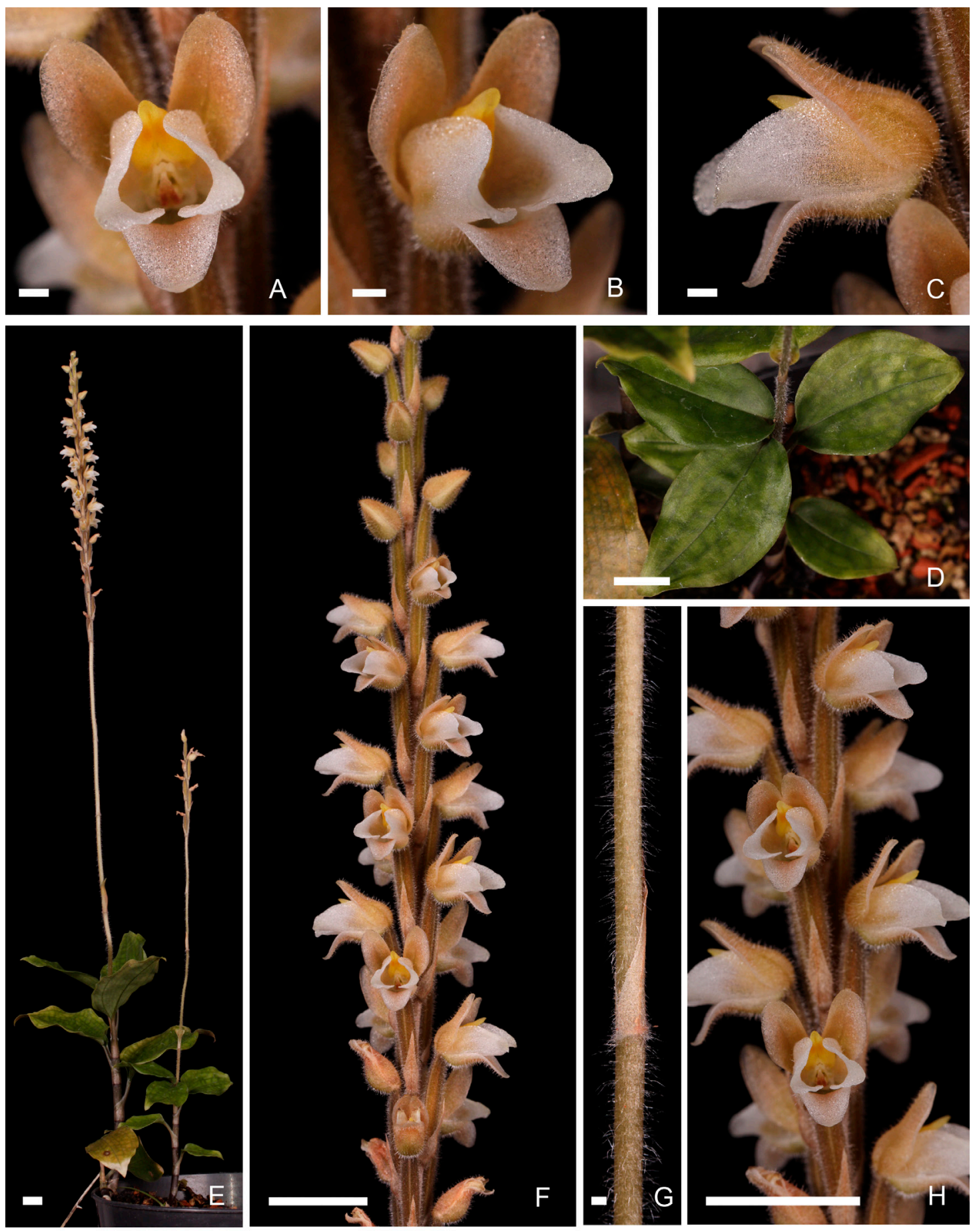

Figure 1. Hetaeria finlaysoniana. A. Flower from the front. B. Flower. C. Flower from the side. D. Leaves. E. Habit. F. Inflorescence. G. Peduncle with sterile bract. H. Closeup of the inflorescence. Scale bars: A, B, C, G = 1 mm; D, E, F, $\mathrm{H}=1 \mathrm{~cm}$. Photo J. Ponert. Cultivated in Prague Botanical Garden (Leg. J. Ponert 523, PRC!). 


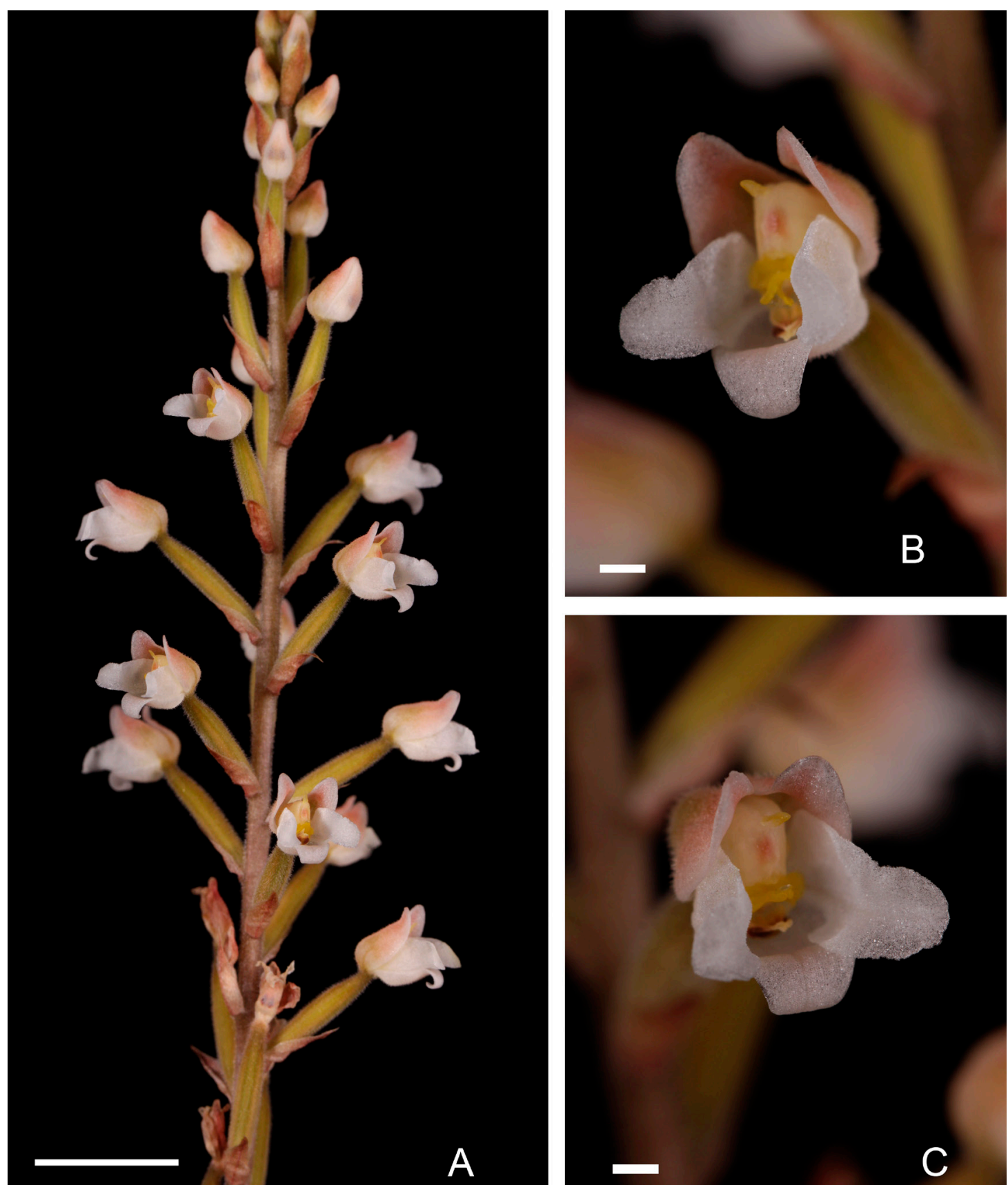

Figure 2. Hetaeria youngsayei. A. Inflorescence. B-C. Details of flowers. Photo J. Ponert. Cultivated in Prague Botanical Garden (Leg. J. Ponert 524, PRC!).

reported from Thailand, Hainan and Hong Kong but not yet from Cambodia or Laos which lie between Vietnam and Thailand. Our collection shows that this species may be distributed not only in northern part of Vietnam, but more likely in nearly the whole country, because of the long distance between available records. Similarly as in $H$. finlaysoniana mentioned above we hypothesize a larger distribution area which may extend from Thailand through Laos and Cambodia to Vietnam, Hainan and Hong Kong. 


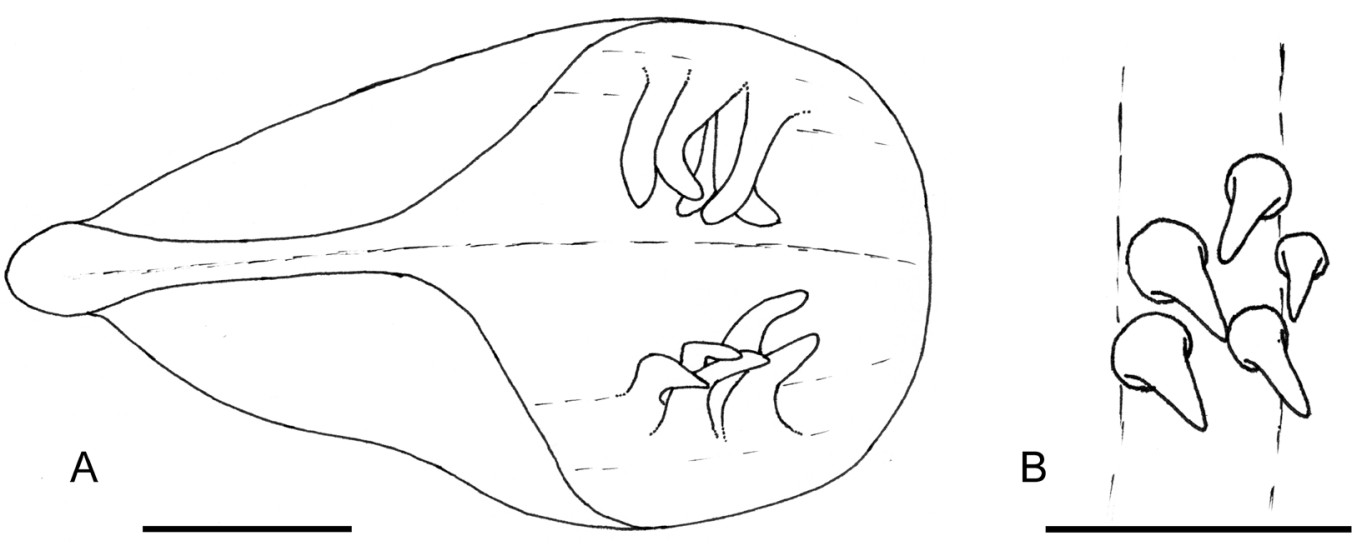

FiguRE 3. Lip of Hetaeria finlaysoniana. A. Lip from above in native shape. B. Top view of a cluster of glands when lip is flattened. Scale bars $=1 \mathrm{~mm}$. Drawn by J. Ponert (Leg. J. Ponert 523, PRC!).

Flowering time. Flowering specimens were observed from January to February in Hon Ba what is the same as reported from other places (Pedersen 2011).

Pollination. We have not observed fruit production in culture from any flower except those which were previously hand-pollinated. Based on this we propose that these plants are allogamous.

Ecology. Plants were growing in leaf litter on a ground in evergreen tropical primary forest with granite bedrock at elevations from about $600 \mathrm{~m}$ to $1000 \mathrm{~m}$ on slopes of the Hon Ba massive. Other terrestrial orchids growing in the similar places are Didymoplexis sp., Erythrorchis altissima (Blume) Blume and Zeuxine affinis (Lindl.) Benth. ex Hook.f..
Specimens seen. Czech Republic, cultivated in Prague Botanical Garden, 17 March 2013 (originally collected in Vietnam, Khánh Hòa province, Cam Lâm District, Hòn Bà Nature Reserve, trail in evergreen tropical forest near the road, alt. $836 \mathrm{~m}, 14$ March 2012), J. Ponert 524 (PRC!).

AcKNowledgements. Authors express their sincere gratitude to all participants of Hon Ba Nature Reserve field trip of 2012. Special expression of thanks belongs to Prague Botanical Garden, Czech Republic, which is sponsoring the biodiversity research of Hon Ba Nature Reserve in the field and the Charles University in Prague (SVV 265203 / 2012) where detailed study of plant material was done. Special thanks belong to anonymous reviewers who significantly improved the manuscript.

\section{Artificial identification key to the Vietnamese species of Hetaeria*}

1a. Lip dividend into hypochile, mesochile and epichile. Epichile large, two-lobed, c. $2.5 \mathrm{~mm}$ wide $\quad H$. anomala 1b. Lip without distinguishable mesochile, epichile entire and very small

2a. Epichile dilated and broadly ovate, apex obtuse H. affinis

2b. Epichile linear, abruptly attenuate, sometimes with a small terminal lobule

3a. Lip basal part inside with 1 to 2 simple or multiarmed glands on either side H. alta

3b. Lip basal part inside with 3 to 8 separated (sometimes connate at base) glands on either side 4

4a. Glands inside the lip fleshy, 3 to 5 on either side, arranged in one dense cluster, inflorescence rather lax

H. youngsayei

4b. Glands inside the lip filiform, 4 to 8 on either side, at least some of them clearly separated from each other, inflorescence rather dense

* This key is based on data from Seidenfaden \& Wood (1992), Ormerod (2004), Averyanov (2008), Lin \& Fu-Wu (2009), Pedersen \& Ormerod (2009), Pedersen (2011) and Chen et al. (2012). 


\section{LiTERATURE CITED}

Averyanov, L. 2008. The orchids of Vietnam, Illustrated Survey, part 1, subfamilies Apostasioideae, Cypripedioideae and Spiranthoideae. Turczaninowia 11: 5-168.

Averyanov, L. V., A. L. Averyanova, P. K. Loc \& N. T. Hiep. 2009. Orchid Flora of Vietnam, New Discoveries and some of their Characteristics. Adv. Nat. Sc. 10: 353-365.

Chen, S., Gale, S. W., Cribb, P. J. \& P. Ormerod. 2012. 16. Zeuxine Lindley. Pp. 7176 in: Chen S., L. Zhongjian, Z. Guanghua, L. Kaiyong, J. Zhanhe, L. Yibo, J. Xiaohua, P. J. Cribb, J. J. Wood, S. W. Gale, P. Ormerod, J. J. Vermeulen, H. P. Wood, D. Clayton \& A. Bell (eds.), Orchidaceae, Flora of China 25. [online at http://flora.huh.harvard.edu/china/ mss/volume25/FOC_25_Orchidaceae_all.pdf, accessed 22 July 2013].

Lin, L. \& Fu-Wu, X. 2009. A New Species of Hetaeria (Orchidaceae) from Hainan, China. Novon 19: 187-190.

Ormerod, P. 2004. Notulae Goodyerinae. Oasis, Suppl. 3: 3-19.

Ormerod, P. \& C. Sathish Kumar. 2003. Orchidaceous additions to the Flora of Burma (Myanmar). Rheedea 13: 43-50.

Pedersen, H. Æ. 2011. 19. Hetaeria. Pp. 156-168 in: Pedersen, H. Æ., H. Kurzweil, S. Suddee \& P. J. Cribb (ed.), Flora of Thailand, Volume 12, Part 1: Orchidaceae 1 (Cypripedioideae, Orchidoideae, Vanilloideae). The Forest Herbarium, Department of National Parks, Wildlife and Plant Conservation, Bangkok.

Pedersen, H. Æ. \& P. Ormerod. 2009. Notes on the Orchid Flora of Thailand (I). Taiwania 54: 213-218.

Pridgeon, A. M., P. J. Cribb, M. W. Chase \& F. Rasmussen. 2003. Genera Orchidacearum: Volume 3: Orchidoideae (Part 2), Vanilloideae. Oxford University Press, Oxford.

Seidenfaden, G. 1997. Contributions to the orchid flora of Thailand XIII. Olsen \& Olsen, Fredensborg, Denmark, pp. 10.

Seidenfaden, G. \& J. J. Wood. 1992. The Orchids of Penninsular Malaysia and Singapore. Olsen \& Olsen, Fredensborg, Denmark, pp. 8996. 